Ritrýnd grein birt 31. desember 2020

\title{
Viðhorf íslenskra barna til íslensku og ensku: Hvað segja pau um íslensku- og enskukennslu í grunnskólum?
}

\author{
Ólöf Björk Sigurðardóttir og Sigríður Sigurjónsdóttir
}
Abstract
Um höfunda
About the authors
Heimildir

Í pessari grein er fjallað um viðhorf íslenskra barna til móðurmálsins og alpjóðamálsins ensku og sérstaklega hugað að hvað pau segja um íslensku- og enskukennslu á yngsta stigi og miðstigi grunnskólans. Greinin byggist á gögnum úr viðtalshluta öndvegisverkefnisins Greining á málfreðilegum afleiðingum stafrens málsambýlis, sem Sigríður Sigurjónsdóttir og Eiríkur Rögnvaldsson stýrðu árin 2016-2019. Innan verkefnisins voru samdar ítarlegar vefkannanir sem 724 börn á aldrinum 3-12 ára svöruðu og 106 barna sérvalið úrtak úr peim hópi kom síðan í viðtöl og frekari prófanir. Hér er unnið úr svörum 40 peirra 106 barna sem tóku pátt í viðtalshluta öndvegisverkefnisins. Börnin sem hér er fjallað um voru valin út frá magni stafræns ílags/máláreitis, par sem helmingur barnanna fékk mikið stafrænt ílag en hinn helmingurinn lítið.

Niðurstöður benda til að viðhorf 3-12 ára barna til beggja mála séu almennt jákvæð og mikið stafrænt ílag virðist ekki hafa neikvæð áhrif á viðhorf til móðurmálsins. Pemagreining á svörum barnanna sýnir að ólík viðhorf til íslensku og ensku má einkum greina í svörum 6-12 ára barna í tengslum við skólastarf. Börnin tengja góða færni í íslensku við íslenskukennslu í skólanum par sem pau læri að tala „rétt mál“. Par telja börn með mikið stafrænt ílag sig hins vegar læra litla ensku pví hana læri pau frekar af pví að horfa á enskt efni og spila tölvuleiki í frítíma sínum. Áhugavert er að börnin telja sig purfa að læra móðurmálið í skóla en erlenda/annað málið ensku telja sum peirra sig læra úti í samfélaginu. Pessar niðurstöður eru í samræmi við niðurstöður annarra nýlegra rannsókna á viðhorfum barna til íslensku- og enskukennslu í grunnskólum. Pær kalla á endurskoðun á kennslu í báđum málum í 1.-7. bekk grunnskóla, par sem kennslan parf að vera einstaklingsmiðaðri og taka mið af breyttri stöðu móðurmálsins og ensku í stafrænu samfélagi nútímans.

Efnisorð: Viðhorf, börn, stafrænt málsambýli, íslensku-/enskukennsla, grunnskólar, erlent/annað mál

\section{Inngangur}

Á undanförnum áratug eða svo hafa orðið miklar breytingar á málumhverfi Íslendinga sem hafa haft víðtæk áhrif á íslenskt málsamfélag. Fyrir pessum breytingum eru ýmsar utanaðkomandi ástæður bæði samfélagslegar og tæknilegar (sjá t.d. Eirík Rögnvaldsson, 2016; Sigríði Sigurjónsdóttur og Eirík Rögnvaldsson, 2018). Af samfélagsbreytingum má m.a. nefna albjóðavæðingu, fjölgun innflytjenda og aukinn straum erlendra ferðamanna hingað til lands. Tækniframfarir undanfarinna ára hafa m.a. getið af sér snjalltækjabyltinguna, gagnvirka tölvuleiki og talstýrð tæki. Snjalltækjabyltingin hefur orðið til pess að fólk hefur nú greiðan aðgang að öðrum menningarheimum í gegnum tölvur, snjallsíma og spjaldtölvur og í gegnum slík tæki hefur fólk einnig ótakmarkaðan aðgang að ýmsu 
erlendu afpreyingarefni á efnisveitum eins og YouTube og Netflix. Samskipti við fólk í fjarlægum löndum hafa einnig orðið einfaldari og greiðari, t.d. í gegnum gagnvirka tölvuleiki og skrif á netinu. Pá hefur talstýring tækja rutt sér til rúms á allra si̊ðustu árum, t.d. svokallaðir stafrænir aðstoðarmenn eins og Google Home og Amazon Alexa en peim er enn ekki hægt að stjórna með pví að tala við pá íslensku. Allar pessar samfélags- og tæknibreytingar hafa leitt til pess að málsambýli íslensku við önnur tungumál hefur orðið nánara, ekki síst málsambýli íslensku og ensku.

Íslenskt málsamfélag er nú mun fjölbreyttara en pað var fyrir pessar breytingar, en einnig hefur enskunotkun aukist í samfélaginu. Enska hefur fengið aukið vægi sem samskiptamál á heimsvísu á pessari öld (sbr. Crystal, 2003) og hún er ríkjandi mál í stafrænum miðlum. Par sem börn og unglingar sækja gjarnan afpreyingu í pessa miðla og eyða par miklum tíma er stór hluti af pví ílagi (e. input) eða máláreiti sem pau fá á ensku (Dagbjört Guðmundsdóttir, 2018; Sigríður Sigurjónsdóttir og Eiríkur Rögnvaldsson, 2018). Pað er pví ekki síst málumhverfi íslenskra barna og unglinga sem hefur breyst og eftir pví sem tækninni fleygir fram, t.d. snjalltæki og stafrænir aðstoðarmenn verða fyrirferðarmeiri hluti af hversdagslegu lífi fólks, eykst stafrænt málsambýli (e. digital language contact) íslensku við ensku.

Tækniframförum undanfarinna ára hefur pví fylgt ný áskorun, stafrænt málsambýli. Markmið öndvegisverkefnisins Greining á málfreðilegum afleiðingum stafrens málsambýlis (e. Modeling the Linguistic Consequences of Digital Language Contact, www.molicodilaco.hi.is) var að skoða pær afleiðingar sem aukið stafrænt málsambýli íslensku og ensku á undanförnum árum hefur haft á ílag, málkunnáttu, málnotkun og viðhorf Íslendinga til íslensku og ensku og varpa ljósi á stöðu og framtíð íslensku á tímum mikilla samfélags- og tæknibreytinga. Verkefnið hlaut priggja ára öndvegisstyrk úr Rannsóknasjóði RANNÍS á árunum 2016-2019 og verkefnisstjórar pess voru Sigríður Sigurjónsdóttir, prófessor, og Eiríkur Rögnvaldsson, prófessor emeritus, við Háskóla Íslands.

Öndvegisverkefnið var afar viðamikið og enn er verið að vinna úr peim gögnum sem safnað var. Beitt var tvenns konar rannsóknaraðferðum. Annars vegar voru samdar fimm mismunandi útgáfur af vefkönnun eftir aldri pátttakenda og hins vegar tekin viðtöl við pátttakendur og lagðar fyrir pá ítarlegri prófanir. Vefkannanirnar voru sendar til 5.418 manna lagskipts handahófskennds úrtaks íslenskra ríkisborgara á aldrinum 3-98 ára, sem skiptust í 11 aldurshópa. Sérstök áhersla var lögð á að ná til barna og unglinga og pví voru t.a.m. 1.500 börn á aldrinum 3-12 ára í úrtakinu. Vefkönnununum var ætlað að gefa yfirlit yfir ílagsmagn pátttakenda, p.m.t. stafrænt ílag, málnotkun, orðaforða og ýmis málfræðileg atriði, bæði á íslensku og ensku, og viðhorf pátttakenda til tungumálanna tveggja. Svarhlutfall var um 41\% í fullorðinskönnuninni (13-98 ára) en um 50\% í barnakönnununum (Sigríður Sigurjónsdóttir og Eiríkur Rögnvaldsson, 2018). Niðurstöðum vefkönnunarinnar var síðan fylgt eftir með frekari prófunum og viðtölum við 240 manna sérvalið úrtak úr hópi peirra sem svöruðu vefkönnuninni, par af voru 106 börn. Í barnaviðtölunum mættu pátttakendur 10 ára og eldri í tvö eins og hálfs tíma löng viðtöl og prófanir en prjú klukkutíma löng viðtöl voru tekin við pátttakendur á aldrinum 3-9 ára. Viðtalskönnununum var ætlað að afla nánari upplýsinga um stöðu íslenskunnar í stafrænu sambýli við ensku og áhrifum pess á málumhverfi, málnotkun og málkunnáttu Íslendinga. Einnig var viðtölunum ætlað að varpa ljósi á viðhorf Íslendinga til íslensku og ensku.

Pessi grein er unnin upp úr meistaraverkefni Ólafar Bjarkar Sigurðardóttur (2020) sem skrifað var innan öndvegisverkefnisins. Meginmarkmið pess var að kortleggja viðhorf yngstu íslensku málhafanna, 3-12 ára barna, til íslensku og ensku, en einnig var leitast við að varpa ljósi á viðhorf barna til skjá- og netnotkunar og hvort magn stafræns ílags í málumhverfi peirra hefði áhrif á viðhorf peirra til tungumálanna tveggja. Notuð var eigindleg rannsóknaraðferð og unnið úr svörum 40 barna á aldrinum 3-12 ára í viðtalshluta öndvegisverkefnisins.

Hér verður fyrst gerð grein fyrir hugtakinu stafrænt málsambýli og fjallað í stuttu máli um fyrri rannsóknir á viðhorfum Íslendinga, sérstaklega barna og unglinga, til íslensku og ensku. Viðhorf málnotenda er eitt af pví sem hefur mikil áhrif á framtíð og lífvænleika tungumála, t.d. ef viðhorf 
málnotenda til annars tungumálsins í tvítyngdu samfélagi er mun jákvæðara en viðhorf til hins getur pað síðarnefnda átt undir högg að sækja (sjá t.d. Pearson, 2007). Pá verður gerð grein fyrir niðurstöðum athugunar á viðhorfum 40 íslenskra barna til móðurmálsins og alpjóðamálsins ensku, eins og pau birtast í viðtalshluta öndvegisverkefnisins. Síðan er komið að meginumfjöllunarefni greinarinnar; hvað viðhorf 6-12 ára barnanna segja um íslensku- og enskukennslu á yngsta stigi og miðstigi grunnskólans. Loks er efni greinarinnar dregið saman í nokkrum lokaorðum.

\section{Stafrænt málsambýli og viðhorf til tungumála}

Málsambýli í einfaldaðri mynd er pegar fleiri en eitt tungumál er í notkun á tilteknum stað á tilteknum tíma (Thomason, 2001, bls. 1). Málsambýli getur verið fjölbreytt og birst á ólíkan hátt en pegar málsambýli tveggja tungumála er náið getur pað haft áhrif bæði á form og notkunarsvið annars málsins eða beggja. Samskipti málhafa sem eiga sér mismunandi móðurmál eru undirstaða málsambýlis og pau hafa par til nýlega að mestu farið fram augliti til auglitis. Með tækniframförum og alpjóðavæðingu undanfarinna ára hafa samskipti fólks hins vegar breyst og pau fara nú að miklu leyti fram í gegnum stafræna miðla, t.d. á netinu. Tækninýjungar hafa pví haft töluverð áhrif á málsambýli tungumála.

Eins og nefnt var í inngangi heyrir einsleitni íslensks málsamfélags nú sögunni til pví samfélagið hefur breyst hratt undanfarin ár og er nú fjölbreyttara en nokkru sinni fyrr, m.a. vegna aukins innflytjenda- og ferðamannastraums. Pá hefur ensk tunga rutt sér til rúms sem alpjóðamál og raunar er yfirtaka ensku á albjóðlegum vettvangi fordæmalaus hvað varðar áhrif á samskipti pvert á landamæri, tungumál og menningu (Birna Arnbjörnsdóttir og Hafdís Ingvarsdóttir, 2018, bls. 4). Rétt eins og víða annars staðar setur enskan svip sinn á íslenskt málsamfélag og er orðin mjög áberandi í málumhverfinu. Petta stafar m.a. af snjalltækjabyltingunni sem hefur myndað nýja tegund málsambýlis, svokallað stafrænt málsambýli. Petta hugtak vísar til samskipta fólks par sem gagnvirk málleg samskipti fara fram í gegnum snjalltæki og aðra stafræna miðla.

Áður en netið kom til sögunnar undir lok 20. aldar hafði enska haslað sér völl um heim allan í gegnum útvarp, sjónvarp, kvikmyndir og tónlist. Petta ílag var pó að mestu óvirkt, p.e. hlustendur og áhorfendur voru viðtakendur tungumálsins með pví að hlusta, horfa og/eða lesa en höfðu ekki endilega tækifæri til virkrar enskunotkunar, p.e. að tala hana og skrifa. Með tilkomu netsins, samfélagsmiðla, tölvuleikja o.fl. sköpuðust síðan fleiri tækifæri fyrir málnotendur til að tjá sig á ensku (Thomason, 2001, bls. 3). Enska hefur pví á skömmum tíma orððð lykiltungumál á mörgum sviðum, ekki síst í hinum stafræna heimi par sem hún er aðalsamskiptamálið og mikilvægi hennar fer stöðugt vaxandi á kostnað annarra tungumála (sjá t.d. umræðu um svokallaðan stafrænan tungumáladauða (e. digital language death) hjá Eiríki Rögnvaldssyni, Kristínu M. Jóhannsdóttur, Sigrúnu Helgadóttur og Steinpóri Steingrímssyni, 2012). Pótt snjalltækjabyltingin sé á margan hátt afar jákvæð próun pá getur hún haft neikvæð áhrif á móðurmál fámennra pjóða eins og Íslendinga (Sigríður Sigurjónsdóttir, 2016). Staða íslensku í hinum stafræna heimi er veik og hefur verið talað um umdæmisvanda hennar á pessu sviði (Eiríkur Rögnvaldsson, 2015; Kristján Árnason, 2001). Eigi íslenska að lifa af hið nána stafræna málsambýli við ensku pá verður hún að skapa sér umdæmi í hinum stafræna heimi og einnig er mikilvægt að viðhorf til hennar séu jákvæð.

Viðhorf málhafa innan málsambýlis til peirra tungumála sem um ræðir geta haft áhrif á hvernig málsambýlið próast og hvort og pá hvaða áhrif pað hefur á móðurmál málhafanna til frambúðar. Í samfélögum manna er ákveðinn virðingarstigi er lýtur að málnotkun, mállýskum og tungumálum og pví er misjafnt hvort viðhorf eru jákvæð eða neikvæð til ákveðinnar málnotkunar, mállýskna og tungumála. Viðhorf til tungumála eru að vissu leyti lærð hegðun sem einstaklingur tileinkar sér snemma á lífsleiðinni en ýmsir utanaðkomandi pættir geta haft áhrif á mótun viðhorfa, m.a. foreldrar, skóli, bókmenntir og hinir ýmsu miðlar. Ólík viðhorf til tungumála mótast í æsku en eitt skýrasta dæmið um pað er að börn eru tiltölulega ung pegar pau fara að gera greinarmun á málnotkun sem fellur undir staðalmál (eða svokallað „rétt mál“) og óformlegt mál í móðurmáli peirra og greina 
á milli málhafa sem nota hvort tilbrigði um sig (Garrett, 2002, bls. 629). Hvaða málbreytingar ná útbreiðslu í tungumálum er að nokkru leyti undir viðhorfum málhafa til máltilbrigðanna komið (Thomason, 2001, bls. 77) og einnig skipta jákvæð viðhorf málhafa sköpum pegar kemur að pví hvort tungumál fámennrar bjóðar lifi af náið sambýli við albjóðlega ríkjandi tungumál (UNESCO Ad Hoc Expert Group on Endangered Languages, 2003, bls. 8). Miðlar, ekki síst stafrænir miðlar, hafa nú til dags sífellt meiri áhrif á viðhorf fólks. Peir móta viðhorf einstaklinga og eru par af leiðandi handhæg tól til útbreiðslu nýrra hugmynda og viðhorfa, bæði jákvæðra og neikvæðra. Breyttar aðstæður á mótunarárum barna í hnattrænu samfélagi nútímans hafa ekki aðeins áhrif á skoðanir peirra á mönnum og málefnum heldur einnig á viðhorf peirra til málnotkunar og tungumála. Börn eiga nú greiðan aðgang að ólíkum hugmyndum og viðhorfum á netinu og pví er líklegra en áður að viðhorf peirra séu önnur en viðhorf foreldranna (Garrett, 2002, bls. 629). Ólík viðhorf barna og foreldra eru ekki síst líkleg til að birtast í viðhorfum til fámennrar pjóðtungu eins og íslenskunnar og alpjóðamálsins ensku.

Íslenska er enn í hugum margra lituð hugmyndum um forskriftarmálfræði og tungumálið enn tengt pjóðerni og litið á pað sem eins konar sameiningartákn, pað sem geri Íslendinga að pjóð og sé eitt helsta pjóðareinkenni peirra (Hanna Óladóttir, 2007, bls. 127). Petta kemur einnig fram í doktorsritgerð Hönnu Óladóttur (2017, bls. 310) par sem hún rannsakaði m.a. málfræðikennslu á unglingastigi í íslenskum grunnskólum og inntak skólamálfræðinnar. Viðmælendur hennar, sem voru bæði kennarar og nemendur, virtust tengja málfræðikennslu við hugmyndir um „rétt mál“ og kennurunum fannst mikilvægt að undirbúa nemendurna sem best undir framtíðina með pví að kenna peim „viðurkennt mál“ sem gæti gagnast peim, bæði innan skólakerfisins og á vinnumarkaði ásamt öðrum opinberum vettvangi. Sömuleiðis fannst nemendum mikilvægt að kunna og nota „rétt mál“ par sem líklegt væri að með pví að vanda málfar sitt og fylgja málstaðlinum öðluðust pau meiri trúverðugleika og virðingu annarra. Einnig kom fyrir að nemendur tengdu petta málsnið við vandvirkni, menntun og jafnvel gáfur. Svipaðar niðurstöður fengust í rannsóknarverkefninu Íslenska sem námsgrein og kennslutunga (İNOK) (Kristján Jóhann Jónsson og Ásgrímur Angantýsson, 2018), par sem Ásgrímur Angantýsson, Finnur Friðriksson og Sigurður Konráðsson (2018) fjölluðu m.a. um viðhorf grunn- og framhaldsskólanema til peirrar málfræðikennslu sem fram fer í íslenskum skólum. Í svörum pátttakenda kom fram áðurnefnt viðhorf til „rétts máls“ og „viðurkennds málfars“. Viðhorf til „hnignunar tungunnar“, hvort leyfa ætti máltilbrigði sem stafa af málbreytingum og eru par af leiðandi „rangt mál“ samkvæmt málstaðlinum, komu einnig fram og sumir nemendur töldu að pjóðtungan gæti jafnvel glatast ef fólk vandaði ekki málfar sitt. Niðurstöður pessara tveggja rannsókna, Hönnu Óladóttur (2017) og ÍNOK-verkefnisins, eru pví samhljóða að pví leyti að viðhorf ungra Íslendinga til móðurmálsins virðast litast mjög af afstöðu til „réttrar og rangrar málnotkunar“.

Íslendingar, bæði börn og fullorðnir, virðast pví átta sig á mikilvægi pess að varðveita íslensku og á mikilvægi hennar í samskiptum á Íslandi. Alpjóðavæðing síðustu ára hefur engu að síður valdið ákveðinni togstreitu í huga peirra par sem málnotendur finna fyrir ábyrgð gagnvart íslensku sem samskiptamáli innanlands en skynja einnig mikilvægi góðrar enskukunnáttu í alpjóðlegu samhengi. Íslensk ungmenni sjá nú ekki endilega fyrir sér að búa á Íslandi í framtíðinni. Spennandi alpjóðleg störf bíða peirra erlendis og góð enskukunnátta opnar fleiri möguleika en góð íslenskukunnátta, sem ólíklegt er að nýtist peim á erlendum vinnumarkaði (sbr. Lilju Björk Stefánsdóttur, 2018a). Ensku er pví nú yfirleitt tekið fagnandi sem samskiptamáli hér á landi, p.e. litið er á hana sem einhvers konar lykil að hinu spennandi og framandi alpjóðasamfélagi og málhöfum virðist yfirleitt finnast peir græða á pví að tala tvö tungumál, íslensku og ensku. Îslendingar virðast pó engu að síður vera meðvitaðir um hættuna sem náið samband tungumálanna tveggja býður upp á og eru að pví leyti tortryggnir í garð enskunnar (Ari Páll Kristinsson, 2017, bls. 107). Jeeves (2010, 2013) rannsakaði virka enskunotkun, p.e. tal og skrif íslenskra ungmenna, og viðhorf peirra til ensku. Niðurstöður hennar sýna að viðhorf peirra til ensku eru almennt jákvæð. Ungmennin telja ensku forsendu samskipta, bæði erlendis og við pá sem ekki tala íslensku hér á landi en einnig í almennum samskiptum við Íslendinga, t.d. pegar pau segja brandara sem pau telja að séu hreinlega fyndnari á ensku en á íslensku (Jeeves, 2010, bls. 10). Ungmennin geta vart hugsað sér lífið án ensku, svo mikilvæg er hún. Hafdís Ingvarsdóttir og Ásrún Jóhannsdóttir (2018) fengu svipaðar niðurstöður er 
pær könnuðu m.a. við hvaða aðstæður nemendur í 10. bekk grunnskóla notuðu helst ensku. Í svörum unglinganna kom í ljós að mest af pví afpreyingarefni sem peir horfðu eða hlustuðu á var á ensku. Um helmingur sagðist nota ensku mest á ferðalögum og á netinu og tæplega fimmtungur sagðist tala ensku við vini, en tiltölulega fáir lásu bækur á ensku pótt fleiri læsu tímarit. Enska virtist einnig vera mikilvægur og nokkuð stór hluti af daglegu lífi ungmennanna, pví um 70\% töldu hana mjög mikilvæga og 27\% töldu hana frekar mikilvæga en aðeins tæplega $2 \%$ töldu hana ekki mikilvæga eða óparfa (bls. 85-86). Pá kom fram að unglingunum fannst enska mikilvæg í samskiptum erlendis og er pað í samræmi við niðurstöður Jeeves (2010).

Niðurstöður pessara rannsókna á stöðu ensku á Íslandi benda til að magn ensku í málumhverfinu og enskunotkun ungra Íslendinga sé talsvert frábrugðin pví sem stjórnvöld vinna út frá, t.a.m. pegar markmið um enskukennslu í grunnskólum eru sett fram. Petta er hinn nýi veruleiki stafrænnar aldar par sem börn fá mun meira enskt ílag og tileinka sér mun meiri ensku en áđur í gegnum ýmiss konar afpreyingu í stafrænum miðlum (Ásrún Jóhannsdóttir, 2010, 2018; sjá einnig Lefever, 2010). Enn er pó litið á ensku sem erlent tungumál (e. foreign language) innan skólakerfisins frekar en annað mál (e. second language) og hún kennd sem slík, en gerður er greinarmunur á pessum hugtökum eftir málumhverfi málhafans pegar hann lærir málið. Talað er um annað mál pegar tungumál er lært á eftir móðurmáli á málsvæði markmálsins en erlent mál pegar menn læra tungumál, yfirleitt í skóla, sem er ekki tungumál málsamfélagsins (Birna Arnbjörnsdóttir, 2013, bls. 209). Niðurstöður rannsókna Birnu Arnbjörnsdóttur $(2011,2018)$ og félaga (sjá bók Birnu Arnbjörnsdóttur og Hafdísar Ingvarsdóttur, 2018) benda til að einmitt vegna magns ensku í málumhverfi Î́lendinga nú á dögum sé ekki lengur forsvaranlegt að flokka ensku sem erlent mál á Íslandi. Einnig er athyglisvert að sum íslensk börn og unglingar telja sjálf að hæfni peirra í ensku sé nær pví að flokkast sem annað mál en erlent mál (Jeeves, 2010).

Í pessu sambandi parf pó að hafa í huga að málaðstæður á Íslandi eru sérstakar að pví leyti að hér hefur orðið til málsambýli par sem annað tungumál en opinbert mál landsins er áberandi, sérstaklega í ákveðnum umdæmum, en pað hefur samt sem áður ekki opinbera stöðu í málsamfélaginu. Á Íslandi er íslenska enn eina opinbera tungumálið, ásamt íslensku táknmáli (lög um stöðu íslenskrar tungu og íslensks táknmáls nr. 61/2011). Aðstæður hér eru pví frábrugðnar mörgum öðrum málsamfélögum par sem tvö eða fleiri tungumál eru opinberlega viðurkennd í samfélaginu og enska jafnvel eitt peirra, eins og t.d. í Kanada par sem enska og franska eru bæði opinber mál. Íslenska er enn ríkjandi mál í íslensku samfélagi, notuð á flestum sviðum pjóðlífsins, t.d. í stjórnkerfinu, skólum, fjölmiðlum og viðskiptum, pótt blikur séu par á lofti (sbr. Eirík Rögnvaldsson, 2016). Íslenska er pví meirihlutamál á Íslandi og enska, og önnur tungumál sem hér eru töluð, minnihlutamál. Mörkin á milli meirihlutamálsins íslensku og minnihlutamálsins ensku verða pó sífellt óskýrari, einkum vegna hins stóra stafræna málumdæmis par sem enska er ríkjandi mál.

Í breyttu málumhverfi samtímans er enska pví orðin stór hluti af íslensku málsamfélagi, og enskt máláreiti nær til yngri barna en nokkru sinni fyrr (sbr. Sigríði Sigurjónsdóttur, 2019; Sigríði Sigurjónsdóttur og Eirík Rögnvaldsson, 2018). Náið sambýli íslensku við ensku í hinum stafræna heimi og víðar hefur og mun hafa áhrif á hugmyndir Íslendinga og viðhorf til tungumálanna tveggja. Pví er afar áhugavert að skoða hvaða viðhorf börn á aldrinum 3-12 ára, sem alist hafa upp í pessu nýja málsambýli, hafa til tungumálanna tveggja, íslensku og ensku.

\section{Viðhorf 3-12 ára barna til tungumálanna tveggja}

Meginmarkmið öndvegisverkefnisins Greining á málfreðilegum afleiðingum stafrans málsambýlis 2016-2019 var að rannsaka áhrif stafrænna miðla og snjalltækja á ílag, málkunnáttu, málnotkun og viðhorf Íslendinga til íslensku og ensku og par með varpa ljósi á stöðu og framtíð íslensku á tímum mikilla samfélags- og tæknibreytinga (Sigríður Sigurjónsdóttir og Eiríkur Rögnvaldsson, 2018). Pessi grein byggir á úrvinnslu gagna úr viðtalshluta öndvegisverkefnisins, en pátttakendur 10 ára og eldri mættu í tvö eins og hálfs tíma löng viðtöl og frekari prófanir en prjú klukkutíma löng viðtöl voru tekin við pátttakendur á aldrinum 3-9 ára. Pessum prófunum og viðtölum var m.a. ætlað að afla nánari 
upplýsinga en fengust í vefkönnununum um viðhorf íslenskra barna til íslensku og ensku. Viðtölin voru hálfskipulögð (e. semi-structured) sem býður upp á frjálst samtal rannsakanda og viðmælanda pótt farið sé eftir ákveðnum leiðarspurningum. Spurningarnar sneru að tungumálanotkun barnanna almennt en einnig að daglegum athöfnum eins og lestri, áhorfi á ýmsa miðla, snjalltækjanotkun o.fl. Á sama tíma og barn mætti í viðtal var einnig tekið sérstakt viðtal við foreldri eða forráðamann pess, en í pví fólst m.a. ítarleg kortlagning á ílagi barnsins á íslensku, ensku og öðrum málum ásamt stafrænu ílagsmagni pess. Niðurstöður úr pessum viðtölum við foreldra um stafrænt ílagsmagn barns peirra voru notaðar til að velja börn í athugunina sem fjallað er um í pessari grein, sbr. Töflu 1 .

Pátttakendur í barnaviðtölunum voru samtals 106 og voru börnin valin úr hópi peirra 724 barna sem svöruðu vefkönnununum út frá svörum foreldra par um magn stafræns ílags peirra (mikið, meðal, lítið). Viðtölin við börnin fóru fram á tímabilinu ágúst 2018 - maí 2019. Pátttakendum var skipt í fjóra aldurshópa: 3-5 ára ( $\mathrm{n}=34), 6-7$ ára $(\mathrm{n}=18), 8-9$ ára $(\mathrm{n}=24)$ og 10-12 ára $(\mathrm{n}=30)$. Í peirri athugun sem gerð er grein fyrir hér eru skoðuð svör 40 barna sem tóku pátt í barnaviðtölunum. Í hverjum aldursflokki voru svör 10 barna skoðuð, en af peim voru 5 börn sem fengu mikið stafrænt ílag daglega og 5 börn sem fengu lítið stafrænt ílag daglega samkvæmt svörum foreldra í áðurnefndum viðtölum sem tekin voru við foreldri eða forráðamann á sama tíma og barn peirra mætti í viðtal. Í hóp barna með mikið og lítið stafrænt ílag voru valin pau 5 börn sem voru annars vegar með mesta og hins vegar minnsta stafræna ílagið í hverjum aldurshópi í viðtalskönnuninni. Samtals voru pví 20 pátttakendur alls í pessari athugun sem fengu mikið stafrænt ílag og 20 sem fengu lítið stafrænt ílag. Skiptingu barnanna eftir aldurshópum og magni daglegs stafræns ílags hvers hóps í mínútum má sjá í Töflu 1:

Tafla 1. Skipting pátttakenda eftir aldurshópum og magni stafræns ílags.

\begin{tabular}{cccc}
\hline Aldurshópur & Mikið ílag & Lítið ílag & Samtals fjöldi \\
\hline 3-5 ára & 5 börn (927 mín) & 5 börn (0 mín) & 10 börn (927 mín) \\
6-7 ára & 5 börn (828 mín) & 5 börn (102 mín) & 10 börn (930 mín) \\
8-9 ára & 5 börn (1.572 mín) & 5 börn (110 mín) & 10 börn (1.682 mín) \\
10-12 ára & 5 börn (2.201 mín) & 5 börn (329 mín) & 10 börn (2.530 mín) \\
\hline Samtals & $\mathbf{2 0 ~ b o ̈ r n ~ ( 5 . 5 2 8 ~ m i ́ n ) ~}$ & $\mathbf{2 0 ~ b o ̈ r n ~ ( 5 4 1 ~ m i ́ n ) ~}$ & $\mathbf{4 0 ~ b o ̈ r n ~ ( 6 . 0 6 9 ~ m i ́ n ) ~}$ \\
\hline
\end{tabular}

Á Töflu 1 sést að mikill munur er á samanlögðu magni stafræns ílags barna sem fá mikið stafrænt ílag og barna sem fá lítið stafrænt ílag í hverjum aldurshópi. Einnig sést að stafrænt ílag eykst eftir pví sem börnin eldast. Ílagsmagn hvers barns í hópi barnanna 20 sem eru með mikið stafrænt ílag er á bilinu 100-500 mínútur daglega en ílagsmagn barnanna 20 sem eru með lítið stafrænt ílag er á bilinu 0-120 mínútur daglega. Rétt er að leggja áherslu á pað sem kom fram hér að framan, að í pessa athugun voru valin pau fimm börn í hverjum aldurshópi sem voru með mesta og minnsta stafræna ílagið daglega í viðtalskönnun öndvegisverkefnisins ( $\mathrm{n}=106)$. Pessi 40 börn eru pví ekki eins dæmigerð fyrir úrtakið allt ( $\mathrm{n}=106)$ og pau börn sem eru nær meðalílagi alls hópsins.

Viðhorfsspurningarnar í viðtölunum snerust m.a. um mat barnanna á eigin hæfni í íslensku og ensku, hvort pað væri gagnlegt að kunna tungumálin tvö og pá af hverju, hvort pau vildu bæta sig í íslensku og ensku og pá hvers vegna, hvort pau reyndu að vanda sig pegar pau töluðu, hvort pau töluðu stundum ensku og pá hvar og hvenær og einnig sneru nokkrar spurningar að notkun á ýmsum stafrænum miðlum og snjalltækjum. Í flestum spurningum mátti greina ákveðin efnisleg pemu í svörum barnanna. Hér var notast við handvirka sniðmátsgreiningu (e. template analysis) par sem viðtölin voru lesin gaumgæfilega og leitast við að finna ákveðin sameiginleg pemu í svörum við hverri spurningu. Pegar flokkað er í pemu er leitast við að finna sameiginlega pætti í svörum viðmælenda sem einkenna viðhorf peirra til spurningarinnar og eru yfirleitt nánari útskýringar á svari peirra. Sem dæmi má nefna að pegar leitað er eftir pemanu forskriftarmálfræði er skoðað 
hvort t.d. hugtökin „rétt mál“, „rangt mál“ og „villur“ komi fram í svörum viðmælandans. Hér var að hluta til byggt á pemagreiningu Lilju Bjarkar Stefánsdóttur (2018b) sem hún vann innan öndvegisverkefnisins. Pemun sem birtust í máli barnanna voru nokkuð fjölbreytt og eins kom fyrir að börnin, sérstaklega pau eldri, nefndu fleiri en eitt pema í svari sínu við sumum spurningunum eða pá að pemun sköruðust að einhverju leyti.

Niðurstöður pemagreiningarinnar sýna að viðhorf barnanna til tungumálanna tveggja eru almennt jákvæð og munurinn á viðhorfum til íslensku og ensku er í raun ekki mikill. Til að mynda telja flest börnin sig góð í báðum tungumálum pótt pau vilji einnig bæta kunnáttu sína í báðum málum. Samskipti eru ákveðið leiðarstef í svörum barnanna, hvort sem litið er til viðhorfa til íslensku eða ensku. Engu að síður hafa tungumálin ólík hlutverk í pessum samskiptum, m.a. ólík umdæmi. Umdæmi íslensku eru samskipti á Íslandi, í hvaða formi sem pau eru, og virðist íslenska almennt vera tekin fram yfir ensku sem samskiptamál pegar tveir eða fleiri Íslendingar eiga í hlut. Umdæmi ensku er hins vegar að vissu leyti víðara en íslensku og margbrotnara. Pað tengist að stórum hluta hinum stafræna heimi en er einnig fólgið í ferðalögum til útlanda og samskiptum við innflytjendur og útlendinga hér heima. Ein helsta skörunin á pessum mismunandi umdæmum tungumálanna tveggja eru einmitt samskipti við innflytjendur og útlendinga hér á landi, par sem aukinn fjöldi innflytjenda og ferðamanna hingað til lands, sem tala ekki íslensku, hefur skapað pær aðstæður að enska er nauðsynlegt samskiptamál við pessa hópa hér innanlands. Pað virðist pó vera skýrt í hugum barnanna að íslenska er enn ríkjandi samskiptamál á Íslandi og pví mikilvægt fyrir alla pá sem kjósa að setjast hér að að ná tökum á íslensku. Sum peirra, allt börn sem fá mikið stafrænt ílag daglega, viðurkenna pó að ákveðnar aðstæður og umræðuefni sem tengjast helst notkun peirra á stafrænum miðlum, t.d. tölvuleikir, valdi pví að pau noti enskar slettur eða tali ensku við íslenska vini sína.

Í hugum barnanna skipta pví bæði tungumálin miklu máli og skipa veigamikinn sess í lífi peirra. Umdæmi tungumálanna eru pó að mestu aðskilin, íslenska á Íslandi en enska erlendis og í hinum stafræna heimi, og pau skarast lítið nema pegar kemur að innflytjendum og útlendingum hér á landi og umræðum um ákveðin efni sem tengjast stafrænni miðlanotkun, par sem samskipti fara að nokkru leyti fram á ensku. Í raun eru viðhorf barnanna til tungumálanna tveggja svo svipuð að erfitt er að greina mun. Pó mátti greina eitt ákveðið pema par sem viðhorf 6-12 ára barna til íslensku og ensku voru ólík, en pað var pegar kom að viðhorfum peirra til íslenskukennslu annars vegar og enskukennslu hins vegar í grunnskólum.

\section{Viðhorf barnanna til íslensku- og enskukennslu í grunnskólum}

Pótt meistaraverkefnið sem hér er til umræðu hafi upphaflega ekki haft pað að markmiði að kanna viðhorf barnanna til kennslu íslensku og ensku varð fljótt ljóst af svörum grunnskólabarnanna að par væri að finna mun á viðhorfum peirra til málanna tveggja.

\section{Viðhorf til íslensku}

Í viðtölunum voru yngstu börnin, 3-5 ára, ekki spurð út í viðhorf sín til íslensku og pví byggir pessi kafli á svörum prjátíu 6-12 ára barna. Öll börnin sem svöruðu spurningunni (n=29): „Finnst pér pú vera góð/ur í íslensku?" voru sammála um að pau væru góð eða ágæt í íslensku. Fæst börnin skýrðu mál sitt frekar en einn viðmælandi í aldurshópi 8-9 ára tengdi hæfni sína við pyngd bóka í skólanum, eins og sjá má í (1), par sem R stendur fyrir rannsakanda og V fyrir viðmælanda:

(1) R: Finnst pér pú vera góð í íslensku?

V: Já, ég er er á undan öllum í bekknum í íslensku (ókei), ég byrjaði á undan öllum öðrum með svona erfiðari bækur, pyngri. 
Pótt öll börnin teldu sig góð eða ágæt í íslensku var meirihluti peirra sammála um að pau vildu verða betri. Pannig svöruðu 76\% peirra spurningunni: „Langar pig að verða betri í íslensku?“ jákvætt, $21 \%$ svöruðu neitandi (af peim voru 4 börn af 6 með mikið stafrænt ílag) og eitt barn sem var með lítið stafrænt ílag svaraði „stundum“. Nokkuð mismunandi var hvers vegna eða á hvaða hátt pau vildu bæta hæfni sína í móðurmálinu en algengasta pemað í svörum barnanna var að pau vildu bæta sig í málfræði móðurmálsins. Málfræðin var iðulega tengd við skólastarf og sérstaklega orðflokkagreiningu, eins og sjá má í (2):

(2) R: Ókei. En myndirðu segja að pig langi til að verða betri i i ensku, í íslensku fyrirgefðu?

V: Ee, svona í málfræði eða pannig?

R: Ja bara almennt sko.

V: Já, já.

R: Eru einhverjar ástæður fyrir pví að pú vilt vera betri? Eitthvað sem pér dettur í hug?

V: Ég er ekki alveg nógu góð í svona að flokka svona æji svona í svona föll eða ekki pú veist pannig heldur svona, hvað heitir svona. Persónufornöfn og svona.

R: Já, svona orðflokkagreina eða eitthvað svona málfræðidót eða eitthvað svoleiðis.

V: Eiginlega bara í svona fornöfnum.

R: Já, ókei. En að tala íslensku?

V: Já, mér finnst pað ekkert mál.

(10-12 ára, mikið stafrænt ílag)

Eins og sjá má hjá pessum tiltekna viðmælanda í hópi 10-12 ára barna virðist málfræðin yfirleitt tengd peim málfræðiverkefnum sem eru sett fyrir í skólanum. Рað sama er uppi á teningnum pegar spurt er: „Er gott að kunna íslensku?“ en öll börnin prjátíu voru sammála henni. Viðmælandinn í (3) telur t.a.m. góða kunnáttu í íslensku sérstaklega gagnast sér við að efla orðaforða sinn og stafsetningarkunnáttu og til að komast áfram í vinnubókum í skólanum. Viðmælandinn í (4) tekur að nokkru leyti undir petta par sem hún telur að pað sé gagnlegt að vera góður í íslensku pegar kemur að háskólanámi, sérstaklega pegar litið er til orðaforða. Hún tengir háskólanám við Ísland og í pví samhengi sé góð íslenskukunnátta nauðsynleg.

(3) R: Já, hvað hérna, hvað er gott við að kunna íslensku, hvað finnst pér?

V: Mmm ... maður getur lært fleiri orðaforða ( $\mathrm{mhm})$ og ... stafsetningu (já), að skrifa orðin rétt og eitthvað (mhm) og svo líka bara læra í vinnubókum og eitthvað.

$$
\text { (8-9 ára, lítið stafrænt ílag) }
$$

(4) V: Útaf pví við búum á Íslandi og kannski pegar pú fer í háskóla pá eru kannski skrítin orð sem pú parft að vita og (mmm) ef pú varst ekki góð í íslensku pá kannski bara veistu pað ekki og $(\mathrm{mm})$ já.

(10-12 ára, lítið stafrænt ílag)

Skólastarf virðist pví hafa mikil áhrif á viðhorf barnanna til færni peirra í móðurmálinu, gagnsemi peirrar færni og hvernig pau vilja bæta færni sína. Skólastarf var einnig algengt pema í niðurstöðum Berglindar Hrannar Einarsdóttur (2019), sem skoðaði viðhorf 48 unglinga á aldrinum 13-16 ára til íslensku og ensku í viðtalshluta öndvegisverkefnisins í meistararitgerð sinni. Niðurstöður pemagreiningar hennar sýna að skólastarf kom mikið við sögu pegar spurt var um hvaða skilning unglingarnir legðu í pað að vera góður í íslensku og ekki síst pegar peir voru spurðir um í hvaða 
aðstæðum pað væri gott að vera góður í íslensku. Færni í móðurmálinu virðist pví vera nátengd árangri í íslensku sem námsgrein í skólanum, bæði í hugum 6-12 ára barna og 13-16 ára unglinga.

Í svörum barnanna við pessum spurningum um íslensku birtast einnig hreintunguviðhorf og forskriftarmálfræði. Í (5) má sjá svör viðmælanda í aldurshópi 8-9 ára par sem hreintunguviðhorf birtast. Honum finnst mikilvægt að auka íslenskan orðaforða sinn til að koma í veg fyrir að hann neyðist til að sletta ensku:

(5) R: Já, langar pig að verða betri i íslensku?

V: U jaa, allavega að læra svona einhver svona orð sem eru pú veist, mig langar ekki að fara of mikið í ensku pví pá eiginlega kann ég aldrei, eða pú veist, ef að einhver fer alveg inn í ensku pá kann hann ekki nógu vel íslenskuna og pá getur hann ekki talað hana nógu vel. Mig langar ekki að vera pannig.

(8-9 ára, mikið stafrænt ílag)

Pá kemur forskriftarmálfræði fram í svörum viðmælandans í (6) par sem hann segir gott að kunna íslensku til að geta átt samskipti við foreldra sína og í pví sambandi sé mikilvægt að tala „rétt mál“:

(6) R: Mhm, en er gott að kunna íslensku?

V: Pað er mjög gott já.

R: Mhm, af hverju finnst pér pað?

V: ... Af pví að ... Af pví að ... Af pví að nefnilega ... mmm ... Ja pað er eiginlega engin ástæða, pað er bara mjög mikilvægt að geta talað við mömmu sína og pabba og ... og mjög mikilvægt að tala rétta íslensku og ...

$$
\text { (6-7 ára, lítið stafrænt ílag) }
$$

Petta hugtak kemur einnig fyrir í svari viðmælandans í (7) pegar hann er spurður hvort hann sé góður í íslensku en hann tengir greinilega góða færni i íslensku við pað að tala „rétt mál“:

(7) V: Nei pú veist, ég er kannski hérna í miðjunni og hérna eru pú veist peir sem eru lélegri í íslensku og hérna eru peir sem eru góðir, pú veist, væri alltaf gaman að já, geta pú veist sagt allt rétt og eitthvað.

$$
\text { (10-12 ára, mikið stafrænt ílag) }
$$

Skólasamfélagið og viðmið sem par gilda, t.d. hreintungustefna og forskriftarmálfræði, hafa pví tvímælalaust áhrif á viðhorf barnanna til íslensku. Annað er pó uppi á teningnum pegar börnin eru spurð um enskukunnáttu.

\section{Viðhorf til ensku}

Öll börnin voru spurð út í viðhorf sín til ensku og pví byggir pessi kafli á svörum fjörutíu 3-12 ára barna. Flest segjast pau kunna einhverja ensku, eða 95\% peirra, og eins og kom fram hér að framan telja pau sig flest góð eða ágæt í henni, eða 90\%. Nokkuð var um að börnin, einnig pau yngstu, tjáðu sig jafnvel óumbeðin á ensku pegar pau voru spurð: „Kannt pú einhverja ensku?“ eins og sjá má í dæmi (8): 
(8) V: Já, kannski $(\mathrm{mhm})$ nei ég held að ég kunni einhver, ég ætla að segja hvaða tungumál ég kann.

R: Já.

V: Okei. Good morning.

R: Good morning.

V: Hello.

R: Hello .... Pannig að pú kannt smá í ensku.

V: And ... What are you doing today?

R: I'm talking to you.

V: Yes!

$\mathrm{R}$ : What are you doing today?

V: I'm talking to you.

R: Oh really (hlær). Hvar lærðirðu ensku?

V: Í iPadinum mínum (mhm). Ég á iPad.

(3-5 ára, mikið stafrænt ílag)

Viðmælandinn í (8) sem er í aldurshópnum 3-5 ára virðist ekki í nokkrum vafa um hvar hann lærði ensku, p.e. af iPad. Nokkur börn gáfu í skyn að pau hefðu alltaf kunnað ensku eða pau hefðu lært ensku án pess að leggja sig fram um pað sérstaklega, eins og í dæmi (9):

(9) R: Og pað, já, og hvernig, hvernig pekkirðu ensku? Hvar hefurðu séð ensku?

V: Ég bara lærði ensku.

R: Er pað? (mmh) Hvar lærðirðu ensku?

V: Ekki neins staðar, ég, bara ég heyrði bara einhvern segja pað (ókei), ég kann one two three four five six seven eight nine ten eleven twelve (vó) og ég kann nei, no $(\mathrm{mhm})$ og yes.

R: Váá. Pað er rosalega flott. Og pekkirðu einhvern sem talar ensku?

V: Já.

R: Er pað?

V: Og póllensku.

(6-7 ára, lítið stafrænt ílag)

Pessi svör barnanna gefa til kynna að enska sé alltumlykjandi í málumhverfi margra peirra frá unga aldri og sum peirra hafi tileinkað sér hana ómeðvitað á máltökuskeiði líkt og um annað mál sé að ræða. Nánari útskýringar barnanna, par sem sum segjast kunna litla ensku og pekkja aðeins nokkra frasa og orðatiltæki, og málsýni sem tekin voru af peim innan verkefnisins að tala ensku sýna pó að enskukunnátta peirra jafnast alls ekki á við færni peirra í móðurmálinu: 
(10) R: Ókei og, ertu góður í ensku?

$\mathrm{V}$ : My en cube ens common right me and on be [?]

R: Hvað var petta?

V: Ég veit ekki einu sinni hvað petta pýðir.

R: Hvar heyrðirðu petta?

V: Ég lærði, ég lærði petta pegar ég var priggja ára.

(3-5 ára, mikið stafrænt ílag)

Líkt og í svörum um íslensku virðast börnin vilja bæta sig í ensku en pó á ólíkum forsendum. Eins og kom fram hér að framan vildu börnin helst bæta sig í málfræði og orðaforða í íslensku til að standa sig betur í skólanum. Hvað varðar ensku nefna flest börnin samskipti pegar pau eru spurð: „Langar pig að verða betri í ensku?" Börnin virðast átta sig á pví að enska er lykillinn að alpjóðlegum samskiptum og pau nefna annaðhvort samskipti við útlendinga og innflytjendur sem pau pekkja hér á landi eða við fólk í útlöndum. Ferðalög eru einnig iðulega nefnd í svörum við spurningunni og pessi tvö pemu, samskipti og ferðalög, eru aðalástæðurnar sem nefndar eru, eins og sjá má í (11)-(13):

(11) R: Af hverju? Af hverju heldurðu að pað sé gott að kunna ensku?

V: Uu, pað er bara eitthvað tungumál sem að flestir kunna.

(8-9 ára, lítið stafrænt ílag)

(12) V: pað er örugglega betra að kunna íslensku útaf pví að pú býrð á Íslandi (já) en svo er gott að líka kunna ensku pví pað er ótrúlega mikið af ferðamönnum og svo ertu að fara til útlanda $(\mathrm{mhm})$ og parft að kunna að tala ensku og $(\mathrm{mhm})$. Já, en pað er allavega mikilvægara íslensku.

(10-12 ára, lítið stafrænt ílag)

(13) V: Út af sumir vinir mínir (já) eins og ég sagði var frá Póllandi. Hann talar alveg smá ensku (já) já, ég get talað við hann stundum út af pví hann kann ekki alveg alla íslensku (mhm).

R: Og notarðu stundum ensku til að tala við hann?

V: Já.

(6-7 ára, mikið stafrænt ílag)

Eins og kemur fram í svörum viðmælandans í (13) virðast sum barnanna nota ensku til að eiga samskipti við vini í leikskólanum eða skólanum sem eru innflytjendur með annað móðurmál en íslensku og hafa ekki náð tökum á íslensku. Pað er áhugavert að börnin nota ensku til samskipta pótt enska sé ekki móðurmál viðmælandans og hann hafi ekki endilega forsendur til að halda uppi samræðum á ensku, ekki frekar en íslenska barnið. Pessi svör sýna að enska er notuð til samskipta á Íslandi við ákveðnar aðstæður.

Í umræðu um stafrænt málsambýli hér að framan kom fram að enska er ríkjandi tungumál í hinum stafræna heimi. Börnin virðast hafa áttað sig á yfirburðastöðu ensku í pessu umdæmi, ef marka má svör viðmælandans í (14) við spurningunni: „Er gott að kunna ensku?“:

(14) V: Já, pað er svona tungumálið sem er mest í tölvum, samfélagsmiðlum, bara eiginlega alls staðar núna.

(10-12 ára, mikið stafrænt ílag) 
Ólíkt spurningum um viðhorf til íslensku, par sem meirihluti viðmælenda tengdi góða færni í íslensku við skólanám, pá telja mörg börnin sig læra ensku af umhverfinu, p.e. af hinu stafræna ílagi sem pau fá frá snjalltækjum og tölvum í frítíma sínum, eins og greina má í orðum viðmælendanna í (15) og (16):

(15) V: Ég tala eiginlega bara sko íslensku og ensku.

R: Ókeei og ert- ertu byrjuð að læra ensku í skólanum?

V: Nei.

R: Nei ókei.

V: Ég læri af YouTube (hlátur).

(6-7 ára, lítið stafrænt ílag)

(16) V: Ég lærði frá tölvuleikjum.

R: Já, ég skil.

V: Inná YouTube og allt pað.

R: Já, ég skil pig, en hérna ertu góður í ensku?

V: Mmmm miðja.

R: Ertu byrjaður að læra ensku í skólanum?

V: Já.

R: Okei hvenær byrjaði pað?

V: Bara pegar, byrjun á árinu.

R: Í fjórða bekk?

V: Já og líka vin, mest af orðunum, pað er svona eins og í barnaskóla, peir eru að kenna okkur svoleiðis ensku og ég, ég kann öll orðin sem peir eru að segja.

R: Já, ég skil, pannig pað er ekki verið að kenna pér neitt nýtt í skólanum?

V: Nei.

(8-9 ára, mikið stafrænt ílag)

Viðmælandanum í(16), sem er með mikið stafrænt ílag, finnst hann ekki læra neitt nýtt í enskutímum í skólanum, par sé aðeins verið að kenna honum orðaforða sem hann hefur pegar á valdi sínu. Í svörum hans kristallast neikvætt viðhorf sumra barnanna til enskukennslu í grunnskólanum. Af svörum viðmælandans í (17), sem einnig er með mikið stafrænt ílag, má ráða að honum leiðist stundum enskukennslan í skólanum, t.d. útfylling vinnubóka, en pegar hann fær að nota enskukunnáttu sína í skapandi skrifum og lestri pá sé gaman:

(17) V: Mér finnst gaman í ensku fyrir utan pegar við purfum að vera að skrifa í vinnubækurnar, en ef við erum að gera eitthvað annað eins og lesa eða gera ritun eða eitthvað pannig pá finnst mér pað rosa gaman.

(10-12 ára, mikið stafrænt ílag) 
Almennt benda niðurstöður pessarar athugunar til pess að 6-12 ára börn með mikið stafrænt ílag telji sig læra litla ensku í enskutímum í skólanum en erfitt er að ráða af svörum peirra 20 barna sem eru með lítið stafrænt ílag hvert viðhorf peirra er til enskukennslu í skólanum, par sem pau tjáðu sig lítið um pað í viðtölunum. Mörg börnin nefna að pau læri ensku úti í samfélaginu og af pví stafræna ílagi sem pau fá í frítíma sínum en pau börn í hópi viðmælenda sem fá mikið stafrænt ílag daglega eru líklegri til að segjast hafa lært ensku á pennan hátt en pau sem fá lítið stafrænt ílag. Pótt fæst barnanna segðust tala ensku við íslenska vini sína pá viðurkenndu sum sem fá mikið stafrænt ílag daglega að pau töluðu ensku eða slettu ensku í samtölum um ákveðin umræðuefni, t.d. í umræðum um enska tölvuleiki og pætti. Ákveðnar aðstæður eða umræðuefni virðast pví valda pví að pau leyfa sér aukna enskunotkun. Samskiptin virðast pó að mestu fara fram á íslensku, pótt ákveðin vandkvæði geti komið upp í slíkum umræðum eins og sjá má í (18):

(18) R: En hérna, okei en spilarðu einhverja fleiri?

V: Ég spi, ekki pað, stundum spila ég við vini mína Minecraft, pað er ekki oft samt.

R: Okei er pað pá pannig að vinir pínir eru bara á öðrum stað skilurðu, peir eru bara heima hjá sér eða eitthvað?

V: Já, já.

R: Bara í gegnum netið?

V: Oftast spilar maður pannig.

R: Eruði pá að tala saman með headset?

V: Já, við erum pá í partý, spjöllum saman.

R: Og eruði að tala saman á íslensku eða ensku?

V: Við tölum saman á íslensku, stundum fer pað að vera smá ruglandi pegar maður er svona, pegar að maður er svona að tala um hluti sem eru á ensku, svona eins og „pistle” eða eitthvað, pá svona „hey geturðu rétt mér pistúlið“ (hlátur).

R: Já (hlátur), pá íslenskar maður pað svona.

V: Já.

(10-12 ára, mikið stafrænt ílag)

Viðmælandinn í (18) kemur raunar inn á athyglisvert atriði par sem hann segir flókið að halda samskiptum eingöngu á íslensku pegar spilaðir eru gagnvirkir tölvuleikir á ensku. Hann segir að samskiptin litist oft af enskum orðum pótt börnin aðlagi pau að einhverju leyti að íslensku málkerfi. Pað er áhugavert og bendir til pess að reglur íslensks málkerfis séu mjög virkar í huga pessara barna.

Eins og komið hefur fram eru snjalltæki og stafrænir miðlar orðnir hluti af daglegu lífi íslenskra barna og niðurstöður viðtalanna benda til að stór hluti stafræns ílags barnanna sé á ensku (sjá Ólöfu Björk Sigurðardóttur, 2020, kafla 4.4). Enskt stafrænt ílag er pví hluti af málumhverfi margra ungra íslenskra barna í dag og eykst eftir pví sem börnin eldast (sbr. Sigríði Sigurjónsdóttur, Irisi Nowenstein, Thorbjörgu Thorvaldsdóttur og Dagbjörtu Guðmundsdóttur, 2020, bls. 612). Að mati sumra 6-12 ára barnanna hefur petta stafræna ílag mun meira að segja um að pau læri ensku heldur en sú enska sem kennd er í grunnskólum landsins. Einnig er rétt að nefna að pótt gagnvirk samskipti barna á ensku í gegnum stafræna miðla virðist ekki vera mikil pá virðast börn sem fá mikið stafrænt ílag daglega hafa meira sjálfstraust pegar pau purfa að tjá sig á ensku en börn sem fá lítið stafrænt ílag daglega, en pau voru greinilega óörugg með enskufærni sína. Viðhorf barnanna til ensku almennt eru jákvæð og virðast ekki litast af magni pess stafræna ílags sem pau fá daglega, en ílagsmagnið hefur engu að síður bein áhrif á pær hugmyndir sem pau gera sér um eigin enskufærni og í tilfelli barna með mikið stafrænt ílag á viðhorf peirra til peirrar enskukennslu sem pau fá í grunnskóla. 


\section{Lokaorð}

Eins og rakið hefur verið í pessari grein eru viðhorf málnotenda eitt af pví sem hefur mikil áhrif á framtíð og lífvænleika tungumála. Niðurstöður athugunar á viðhorfum fjörutíu 3-12 ára íslenskra barna, sem tóku pátt í viðtalshluta öndvegisverkefnisins Greining á málfraðilegum afleiðingum stafrans málsambýlis, til móðurmálsins og alpjóðamálsins ensku, benda til að viðhorf peirra til beggja mála séu almennt jákvæð. Áhugavert er að pað sem einna helst greinir á milli viðhorfa til tungumálanna tveggja eru ólík viðhorf sumra 6-12 ára barnanna til íslensku- og enskukennslu í grunnskólum. Pannig tengja börnin góða færni í íslensku við íslenskukennslu í skólanum, par sem pau læri að tala „rétt mál“ sem sé nauðsynlegt til að öðlast virðingu eldri kynslóða og styrkja stöðu sína í samfélaginu. Góða kunnáttu í ensku tengja sum peirra hins vegar ekki enskukennslu í skólanum, pví par telja börn sem fá mikið stafrænt ílag daglega sig læra litla ensku. Hana læri pau frekar af umhverfinu, p.e. pví stafræna ílagi sem pau fá frá snjalltækjum og tölvum í frítíma sínum. Börn sem fá mikið stafrænt ílag daglega eru líklegri til að segjast hafa lært ensku á pennan hátt en börn sem fá lítið stafrænt ílag. Niðurstöður pessarar athugunar benda einmitt til að stafrænt ílag barnanna sé að miklu leyti á ensku og niðurstöður öndvegisverkefnisins sýna að enskt ílag eykst eftir pví sem börnin eldast (sbr. Irisi Eddu Nowenstein, Dagbjörtu Guðmundsdóttur og Sigriß̉i Sigurjónsdóttur, 2018; Sigríði Sigurjónsdóttur o.fl., 2020) og að magn stafræns ílags hefur jákvæð áhrif á enskan orðaforða peirra (Sigríður Sigurjónsdóttir o.fl., 2020).

Pessi svör barna með mikið stafrænt ílag daglega gefa til kynna að enska sé alltumlykjandi í málumhverfi peirra frá unga aldri og sum peirra hafi tileinkað sér hana ómeðvitað á máltökuskeiði líkt og um annað mál sé að ræða frekar en erlent mál (sjá einnig Birnu Arnbjörnsdóttur, 2011, 2018). Erfitt er pó að segja til um hvort enska sé raunverulega að verða annað mál sumra íslenskra barna og unglinga eða flokkist enn sem erlent mál á Íslandi. Ætla má að til pess að hægt sé að fullyrða að svo sé pyrfti enskt ílag að vera enn meira og fjölbreyttara að gerð í málumhverfinu og pað pyrfti að ná til allra barna, en magn pess enska ílags sem börn fá á máltökuskeiði er breytilegt (sjá Irisi Eddu Nowenstein o.fl., 2018; Sigríði Sigurjónsdóttur o.fl., 2020). Samkvæmt niðurstöðum pessarar athugunar virðast sum börn telja sig allt að pví altalandi á ensku er pau mæta í 1. bekk grunnskóla en önnur segjast kunna litla ensku og pekkja aðeins nokkra frasa og orðatiltæki. Pessar niðurstöður athugunarinnar geta pó stafað af pví hvernig börnin fimm í hverjum ílagshópi voru valin í pessa athugun $(n=40)$, p.e. valin voru pau fimm börn í hverjum aldurshópi sem voru með mesta og minnsta stafræna ílagið daglega í viðtalskönnun öndvegisverkefnisins $(\mathrm{n}=106)$. Börnin í pessari athugun eru pví ekki eins dæmigerð fyrir úrtakið allt $(\mathrm{n}=106)$ og börn sem eru nær meðalílagi hópsins alls. Í pessu sambandi er einnig rétt að hafa í huga að enn er misjafnt á milli skóla á hvaða aldri enskukennsla hefst, en grunnskólar hafa leyfi til að byrja enskukennslu að einhverju leyti áður en kennsla ensku hefst í 4. bekk samkvæmt lögum. Sum börn hefja pví enskunám sitt î 1. bekk eða jafnvel í leikskóla (Birna Arnbjörnsdóttir og Hafdís Ingvarsdóttir, 2018, bls. 6).

Nánari útskýringar barnanna og ensk málsýni sem tekin voru af peim innan öndvegisverkefnisins sýna pó að enskukunnátta peirra jafnast alls ekki á við færni peirra í íslensku. Niðurstöður pessarar athugunar og fyrri rannsóknir á stöðu ensku á Íslandi (sjá t.d. Ásrúnu Jóhannsdóttur, 2010, 2018; Jeeves, 2010; Birnu Arnbjörnsdóttur og Hafdísi Ingvarsdóttur, 2018) benda pó til að magn ensku í málumhverfinu og enskunotkun margra ungra Íslendinga sé talsvert frábrugðin pví sem stjórnvöld vinna út frá, t.a.m. pegar markmið um enskukennslu í grunnskólum eru sett fram. Petta er hinn nýi veruleiki stafrænnar aldar par sem börn fá mun meira enskt ílag og tileinka sér mörg hver mun meiri ensku en áđur í gegnum ýmiss konar afpreyingu í stafrænum miðlum. Í pessu sambandi er einnig áhugavert að börnin telja sig purfa að læra móðurmálið í skóla en erlenda/annað málið ensku telja sum peirra sig læra úti í samfélaginu. Pessar niðurstöður kalla á endurskoðun kennslu í báðum málum í 1.-7. bekk grunnskóla, par sem kennslan parf að vera einstaklingsmiðaðri og taka mið af breyttri stöðu móðurmálsins og ensku í stafrænu samfélagi nútímans. 


\section{Icelandic Children's Attitudes towards Icelandic and English: What do they tell us about the teaching of Icelandic and English in elementary schools?}

The Icelandic language community has changed drastically in recent years due to rapid sociological and technological developments. On the social side, globalization, an explosion in tourism, and a rising number of immigrants have led to increased language contact between Icelandic and English. On the technological side, recent advancements, for example the enhanced usage of smart devices, tablet computers, and voice-controlled electronic equipment, have brought Icelandic into digital language contact with English. These changes were the motivation for the research project Modeling the Linguistic Consequences of Digital Language Contact (http://molicodilaco.hi.is). This three-year project (2016-2019), financed by a Grant of Excellence from the Icelandic Research Fund, was awarded to Sigríður Sigurjónsdóttir, professor, and Eiríkur Rögnvaldsson, professor emeritus, at the University of Iceland.

The main goals of the project were to construct a nation-wide profile of the amount of Icelandic and English input that Icelandic speakers of different ages receive, their attitudes to Icelandic and English, and their language use and competence in both languages. The project included an online survey sent to a stratified random sample of 5,418 speakers aged 3-98 in addition to in-depth interviews and further testing sessions with a group of 240 speakers selected from the participants in the online survey according to certain criteria. 724 children, aged 3-12, responded to the online survey, which was partly parent-administrated; 106 of these children were selected to participate in the indepth testing sessions. The 3-9-year-old participants were interviewed three times, for one hour each time, whereas participants 10 years or older were interviewed twice, for one and a half hours each time.

In this article, which is based on Ólöf Björk Sigurðardóttir's (2020) MA-thesis, we focus on the attitudes of 40 children, aged 3-12, towards their native tongue, Icelandic, and the global language, English. The data comes from interviews within the in-depth testing sessions. The children were divided into four age groups: $3-5,6-7,8-9$, and 10-12-years-old, respectively. Each age group included 10 children, 5 of whom received a lot of digital language input daily and 5 of whom did not. The results of the study suggest that Icelandic children in general have positive feelings towards both languages. A common theme in the children's responses is that both languages are necessary for communication, although their domains are different. The children associate Icelandic with communication within Iceland, where everyone should speak Icelandic. On the other hand, they associate English with travel abroad, communication with immigrants in Iceland, who don't speak Icelandic, and the discussion of certain topics. Thus, certain circumstances demand the use of English in Iceland, for example where not every child in the conversation group is fluent in Icelandic, or when the group is discussing such topics as English computer games or TV programs. The amount of digital language input the children receive daily does not affect their general attitudes towards Icelandic and English, although the children who receive a lot of digital input daily are the ones admitting to using English when playing computer games and using digital media.

Differences in attitudes towards the two languages surface most notably in the 6-12-yearold children's answers to questions regarding schoolwork and the teaching of Icelandic and English in elementary school (grades 1-7). The children associate good knowledge of Icelandic with the teaching of Icelandic at school, where they learn to speak grammatically "correct" Icelandic. On the other hand, the children who receive a lot of digital input do not believe that they learn much English in school. They say they learn English in their spare time, from watching TV-shows on Netflix and YouTube, and from playing computer games. These results are consistent with those of previous studies, e.g., Hanna 
Óladóttir (2017), Ásgrímur Angantýsson et al. (2018), Ásrún Jóhannsdóttir (2010, 2018), Jeeves (2010), and Birna Arnbjörnsdóttir \& Hafdís Ingvarsdóttir (2018), indicating that 6-12-year-old Icelandic children believe that they have to have formal teaching in their native language at school, whereas some of them do not think they need formal teaching in the foreign/second language English, which they now learn extramurally through contextual learning. Children who receive a lot of digital input daily are more likely to say that they learn English in this way, and they are also more confident in their ability to speak English than children with less digital input. Overall, these findings indicate that a re-evaluation of the teaching of both languages in elementary school is called for. Thus, the approach to teaching English has to be more individualized since the status of English is now for some children more like that of a second than a foreign language. Moreover, the teaching of Icelandic should not focus so much on prescriptive standards, but rather emphasize the children's knowledge of Icelandic, which is a modern living language.

Key words: Language attitudes, children, digital language contact, teaching of Icelandic/ English, elementary schools, foreign/second language

\section{Um höfunda}

Ólöf Björk Sigurðardóttir (olof@menntaborg.is) er íslenskukennari við Menntaskóla Borgarfjarðar. Hún lauk BA-prófi i íslensku frá Háskóla Íslands árið 2018 og MA-prófi i íslenskukennslu frá sama skóla árið 2020. Lokaverkefni hennar til meistaraprófs fjallaði um áhrif stafræns málsambýlis íslensku og ensku á viðhorf barna til tungumálanna tveggja og var skrifað undir leiðsögn Sigríðar Sigurjónsdóttur prófessors.

Sigríður Sigurjónsdóttir (siggasig@hi.is) er prófessor í íslenskri málfræði við Íslenskuog menningardeild Háskóla Îslands. Hún lauk doktorsprófi frá University of California í Los Angeles árið 1992 og hefur starfað við Háskóla Íslands frá 1994, sem prófessor frá 2010. Sérsvið hennar eru máltaka barna, málbreytingar í íslensku nútímamáli og stafrænt málsambýli íslensku og ensku. Hún hefur birt fjölmargar ritrýndar greinar á peim sviðum.

\section{About the authors}

Ólöf Björk Sigurðardóttir (olof@menntaborg.is) is a teacher of Icelandic at Borgarfjörður Junior College. She received a BA degree in Icelandic from the University of Iceland in 2018 and an MA-degree in the Teaching of Icelandic from the same university in 2020. In her MA thesis, she investigated the effects of digital language contact with English on the attitudes of 40 Icelandic children, aged 3-12, towards the two languages (advisor Professor Sigríður Sigurjónsdóttir).

Sigríður Sigurjónsdóttir (siggasig@hi.is) is professor of Icelandic language in the Faculty of Icelandic and Comparative Cultural Studies at the University of Iceland. She received her Ph.D. from the University of California at Los Angeles in 1992 and has been employed at the University of Iceland since 1994 - as a full professor since 2010. She specializes mainly in first language acquisition, language change and language contact, and has written a number of peer reviewed articles on those subjects. 


\section{Heimildir}

Ari Páll Kristinsson. (2017). Málheimar. Sitthvað um málstefnu og málnotkun. Reykjavík: Háskólaútgáfan.

Ásgrímur Angantýsson, Finnur Friðriksson og Sigurður Konráðsson. (2018). Málfræði og málfræðikennsla. Í Kristján Jóhann Jónsson og Ásgrímur Angantýsson (ritstjórar), Íslenska i grunnskólum og frambaldsskólum (bls. 135-173). Reykjavík: Háskólaútgáfan.

Ásrún Jóhannsdóttir. (2010). English in the 4th grade in Iceland: Exploring exposure and measuring vocabulary size of 4th grade students. Rádstefnurit Netlu - Menntakvika 2010. Sótt af http://netla.hi.is/menntakvika2010/007.pdf

Ásrún Jóhannsdóttir. (2018). English exposure and vocabulary proficiency at the onset of English instruction. Í Birna Arnbjörnsdóttir og Hafdís Ingvarsdóttir (ritstjórar), Language development across the lifespan: The impact of English on education and work in Iceland (bls. 57-78). Cham: Springer.

Berglind Hrönn Einarsdóttir. (2019). Viðhorf unglinga til íslensku og ensku. Niðurstöður viðtalskönnunar við 48 unglinga á aldrinum 13-16 ára (meistararitgerð í íslenskri málfræði). Sótt af http://hdl.handle.net/1946/32654

Birna Arnbjörnsdóttir. (2011). Exposure to English in Iceland: A quantitative and qualitative study. Ráðstefnurit Netlu-Menntakvika 2011. Sótt af http://netla.hi.is/ menntakvika2011/ 004.pdf

Birna Arnbjörnsdóttir. (2013). Chomsky og kenningar um tileinkun annars máls og erlendra mála. Í Höskuldur Práinsson og Matthew Whelpton (ritstjórar), Chomsky: Mál, sál og samfélag (bls. 207-226). Reykjavík: Háskólaútgáfan.

Birna Arnbjörnsdóttir. (2018). The policies and contexts that frame English education and use in Iceland. Í Birna Arnbjörnsdóttir og Hafdís Ingvarsdóttir (ritstjórar), Language development across the life span: The impact of English on education and work in Iceland (bls. 19-34). Cham: Springer.

Birna Arnbjörnsdóttir og Hafdís Ingvarsdóttir (ritstjórar). (2018). Language development across the life span: The impact of English on education and work in Iceland. Cham: Springer.

Crystal, D. (2003). English as a global language (2. útgáfa). Cambridge: Cambridge University Press.

Dagbjört Guðmundsdóttir. (2018). Aldursbundin próun stafrens ílags i málsambýli islensku og ensku: Kortlagning á umfangi, eðli og áhrifsbreytum (meistararitgerð í íslenskri málfræði). Sótt af https://skemman.is/handle/ $1946 / 29954$

Eiríkur Rögnvaldsson. (2015). Verður íslenska gjaldgeng í stafrænum heimi? Hugrás, vefrit Hugvísindasviðs Háskóla Íslands. Sótt af http://hugras.is/2015/10/verdur-islenska-gjaldgeng-i-stafraenum-heimi/

Eiríkur Rögnvaldsson. (2016). Um utanaðkomandi aðstæður íslenskrar málpróunar. Skírnir, 190(vor), 17-31.

Eiríkur Rögnvaldsson, Kristín M. Jóhannsdóttir, Sigrún Helgadóttir og Steinpór Steingrímsson. (2012). Íslensk tunga á stafranni öld / The Icelandic language in the digital age [META-NET White Paper Series]. Berlín: Springer.

Garrett, P. (2002). Language attitudes and sociolinguistics. Journal of Sociolinguistics, 5(4), 626-631.

Hafdís Ingvarsdóttir og Ásrún Jóhannsdóttir. (2018). Learning and using English: The views of learners at the end of compulsory education. Í Birna Arnbjörnsdóttir og Hafdís Ingvarsdóttir (ritstjórar), Language development across the life span: The impact of English on education and work in Iceland (bls. 79-94). Cham: Springer.

Hanna Óladóttir. (2007). „Ég parf engin fornrit til að vita að ég er Íslendingur, ég vil samt tala íslensku“: Um viðhorf Íslendinga til eigin tungumáls. Ritið, 7(1), 107-130.

Hanna Óladóttir. (2017). Skólamálfraði: Hver er hún og hver atti hún að vera? Um markmið og áhrif málfraðikennslu á unglingastigi grunnskólans (doktorsritgerð í íslenskri málfræði). Sótt af https://opinvisindi.is/ handle/20.500.11815/393

Iris Edda Nowenstein, Dagbjört Guðmundsdóttir og Sigríður Sigurjónsdóttir. (2018). Að tileinka sér móðurmál í tæknivæddum heimi. Skima 41, 17-21.

Jeeves, A. (2010). English at secondary school: Perceptions of relevance. Rádstefnurit Netlu-Menntakvika 2010. Sótt af http://netla.hi.is/menntakvika2010/002.pdf

Jeeves, A. (2013). Relevance and the L2 self in the context of Icelandic secondary school learners: Learner views (doktorsritgerð í ensku). Sótt af http://hdl.handle.net/1946/16755

Kristján Árnason. (2001). Málstefna 21. aldar. Málfregnir 11, 3-9. 
Kristján Jóhann Jónsson og Ásgrímur Angantýsson (ritstjórar). (2018). Íslenska í grunnskólum og framhaldsskólum. Reykjavík: Háskólaútgáfan.

Lefever, S. (2010). English skills of young learners in Iceland: „I started talking English when I was 4 years old. It just bang ... just fall into me.“. Rádstefnurit Netlu - Menntakvika 2010. Sótt af http://netla.hi.is/ menntakvika2010/021.pdf

Lilja Björk Stefánsdóttir. (2018a). Heimdragar og heimsborgarar: Menningarlegur hvati i stafranu málsambýli (meistararitgerð í íslenskri málfræði). Sótt af http://hdl.handle.net/1946/29936

Lilja Björk Stefánsdóttir. (2018b). Pemagreining (óútgefin skýrsla). Reykjavík: Háskóli Íslands.

Lög um stöðu íslenskrar tungu og íslensks táknmáls nr. 61/2011.

Ólöf Björk Sigurðardóttir. (2020). Tungumál og taknivadd börn: Viðhorf barna til islensku og ensku og tengsl peirra við skjá- og netnotkun (meistararitgerð í íslenskri málfræði). Sótt af http://hdl.handle.net/1946/35319

Pearson, B. Z. (2007). Social factors in childhood bilingualism in the United States. Applied Psycholinguistics, 28, 399-410.

Sigríður Sigurjónsdóttir. (2016). Snjalltækjavæðingin og máltaka íslenskra barna. Hugrás, vefrit Hugvísindasviðs Háskóla Íslands. Sótt af http://hugras.is/2016/08/ snjalltaekjavaedinginog-maltaka-islenskra-barna/

Sigríður Sigurjónsdóttir. (2019). Ljáđu mér eyra: Framtíð íslenskunnar og málumhverfi ungra barna. Skirnir, 193(vor), 47-67.

Sigríður Sigurjónsdóttir og Eiríkur Rögnvaldsson. (2018). Stafrænt sambýli íslensku og ensku. Rádstefnurit Netlu - Menntakvika 2018. Sótt af http://netla.hi.is/serrit/2018/menntakvika_2018/05.pdf

Sigríður Sigurjónsdóttir, Iris Nowenstein, Thorbjörg Thorvaldsdóttir og Dagbjört Guðmundsdóttir. (2020). Contact without contact: English digital language input and its effects on L1 Icelandic. Í Megan M. Brown og Alexandra Kohut (ritstjórar), Proceedings of the 44th Boston University conference on language development (bls. 606-619). Somerville, MA: Cascadilla Press.

Thomason, S. (2001). Language contact: An introduction. Edinburgh: Edinburgh University Press.

UNESCO Ad Hoc Expert Group on Endangered Languages. (2003). Language vitality and endangerment. Sótt af http://www.unesco.org/new/fileadmin/MULTIMEDIA/HQ/CLT/pdf/Language_vitality_and_endangerment_EN.pdf

Ólöf Björk Sigurðardóttir og Sigríður Sigurjónsdóttir. (2020).

Viðhorf íslenskra barna til íslensku og ensku: Hvað segja pau um íslensku- og enskukennslu í grunnskólum?

Netla - Veftímarit um uppeldi og menntun: Sérrit 2020 - Menntavika 2020.

Sótt af http://netla.hi.is/serrit/2020/menntavika_2020/03.pdf

DOI: https://doi.org/10.24270/serritnetla.2020.9 
Netla - Veftímarit um uppeldi og menntun:

Sérrit 2019 - Menntakvika 2020 